\title{
PEMBERDAYAAN WANITA MANTAN TKW MELALUI PEMANFAATAN LIMBAH PLASTIK SEBAGAI USAHA KERAJINAN RUMAHAN (STRATEGI PENGURANGAN ARUS BALIK TKW KE LUAR NEGERI)
}

\author{
Drs. Chakam Failasuf, M.Pd \\ Fakultas Bahasa dan Seni Universitas Negeri Jakarta
}

\begin{abstract}
ABSTRAK
Pengiriman Tenaga Kerja Wanita (TKW) ke Luar Negeri adalah sebagai salah satu solusi dari persoalan pengangguran untuk bisa meningkatkan ekonomi keluarga, khusunya untuk wanita yang berasal dari masyarakat berpenghasilan rendah. TKWyang sudah kembali ke Tanah air, pada umumnya adalah wanita usia produktif dan menjadi pengangguran. Agar tidak kehilangan mata pencaharian dan dapat terus bekerja untuk menopang ekonomi keluarga, diperlukan upaya pemberdayakan mantan TKW tersebut melalui pelatihan kerajianan dengan memanfaatkan limbah plastik untuk menambah penghasilan dan meningkatkan ekonomi keluarga.

Pelatihan kerajinan ini bertujuan untuk menciptakan lapangan kerja baru dan diharapkan apresiasi dan perilaku peserta meningkat serta berorientrasi pada peningkatan taraf kehidupan. Pembuatan souvenir atau industri rumahan yang berbahan dasar plastik menggunakan jenis Polietilena yang merupakan plastik yang paling banyak diproduksi seperti bungkus kopi permen, bungkus minuman atau makanan instant, bungkus deterjen dan bungkus-bungkus lain yang bisa dimanfaatkan untuk kerajinan industri rumahan.

Pelaksanaan kegiatan ini dilakukan mulai tanggal 26 Agustus sampai 2 September 2016 di Desa Rowokembu Kecamatan Wonopringgo Pekalongan, Jawa Tengah. Kegiatan dilakukan dengan cara pelatihan mandiri dan berkelompok secara tutorial langsung dari instruktur yang mendampinginya di salah satu rumah warga peserta pelatihan. Selain masyarakat yang mengikuti pelatihan, pihak yang terlibat dalam program ini adalah, UPT LPM UNJ, Pemerintah kota /daerah melalui instansi yang terkait, serta didukung oleh Pembiayaan Program yang berasal dari Anggaran Program, Rincian Anggaran Proses Pelatihan, Rincian Anggaran Peralatan dan Perlengkapan, dan Rincian Manajemen pelaksanaan dan evalusi kegiatan

Setelah peserta mengikuti proses pelatihan, mendapatkan dukungan dan pendampingan hingga mampu memproduksi barang jadi kerajinan, dari kegiatan ini diharapkan dapat akan terbentuk suatu Kelompok Swadaya Masyarakat yang produktif serta mampu menghasilkan produk yang dapat diserap oleh pembeli, memacu peserta untuk mengembangkan dan menciptakan produk-produk kerajinan souvenir. Kegiatan ini diharapkan pula dapat menjadi menjadi usaha alternatif peningkatan ekonomi keluarga melalui pemanfaatan limbah plastik

Dukungan Pemerintah Desa dan Pemerintak Kota dapat berupa memasukan kegiatan pemberdayaan dalam perencanaan pembangunan di desa dengan memperhatikan masalah yang dihadapi warga dari semua sektor yang meliputi epoleksosbudhankam yang seimbang dan merata, Meningkatkan partisipasi masyarakat dengan melakukan pembangunan secara partisipatif sehingga dapat memperlancar dan mempercepat proses pembangunan ditengah-tengah masyarakat. Membangun kemitraan antara peserta dengan pemerintah desa dan pemerintah kota yang berperan sebagai agen promosi melalui pameran dan dianggap sebagai produk unggulan wilayahnya, agar produk yang dihasilkan dari pelatihan bisa menjadi ikon daerah tersebut.
\end{abstract}

\section{PENDAHULUAN}

\section{A. LATAR BELAKANG}

Pertumbuhan masyarakat di Indonesia yang hingga tahun 2016 ini telah lebih dari 200 juta jiwa dengan komposisi wanita lebih banyak dari pada laki-laki. Adapun pertumbuhan penduduk ini mempunyai masalah tersendiri dengan semakin bertambahnya masyarakat usia produktif. Usia produktif ini sebagai modal kekayaan sumber daya manusia yang dapat dimanfaatkan sebagai tenaga kerja yang pruduktif. 
Pertumbuhan yang besar ini dapat berdampak terjadinya pengangguran terbuka dengan segala persoalan. Sebagai solusi dari persoalan pengangguran memilih menjadi tenaga kerja di luar negeri sebagai solusi untuk bisa meningkatkan ekonomi keluarga, karena mereka dari masyarakat berpenghasilan rendah. Khususnya wanita, yang mempunyai kesempatan untuk bekerja sangat terbatas, sehingga mereka harus berjuang menjadi TKW di negeri orang. Karena dengan alasan ekonomi mereka harus mencari pekerjaan menjadi profesi sebagai pembantu rumah tangga.

Menjadi tenaga kerja wanita di luar negeri itu mempunyai batasan kontrak yang dibatasi waktu. Ketika kontrak kerja sudah habis otomatis TKW itu harus pulang kampung kembali. TKW yang memungkinkan mereka akan kembali menjadi TKW di luar negeri, namun banyak juga yang tidak kembali ke luar negeri karena terkendala beberapa alasan. Jumlah TKW yang pulang ke kampung ini cukup banyak, sehingga menjadi persoalan tersendiri bagi diri, lingkungan, maupun negara. Jumlah yang cukup banyak ini, tidak seharusnya menjadi obyek namun dapat diubah ke arah yang lebih berguna dengan pola pemberdayaan (empowering) atau belajar kecakapan hidup (Life skills Education), sebagai solusi sosial yang terjadi di masyarakat.

Tenaga kerja wanita ini mendominasi jumlah tenaga kerja. Masyarakat Indonesia dan khususnya yang berjenis kelamin wanita merupakan hal yang semestinya menjadi perhatian penuh berbagai pihak. Para kaum wanita mantan TKW ini juga masih sebagai masyarakat usia kerja yang masih menganggur dapat diberikan suatu pelatihan agar bisa memberi penghasilan untuk kehidupannya itu sangat membutuhkan pendampingan dan pelatihan keterampilan agar mereka bisa menghasilkan sesuatu karya dan menambah penghasilan mereka.

Pelatihan ini memanfaatkan berbagai keterampilan yang bisa menjadi solusi meningkatkan penghasilan rumah tangga. Salah satu pelatihan yang mungkin diadakan adalah pemanfaatan sampah plastik sebagai kerajinan industri rumahan yang dapat dijadikan souvenir yang bermanfaat.

Pemanfaatan limbah sampah plastik ini cukup banyak didapat di lingkungan masyarakat yang biasa dibuang sebagai sampah. Sampah plastik ini bisa djadikan kerajinan sebagai industry rumahan yang cukup unik bisa dimafaatkan. Melalui pelatihan ini mantan TKW dan wanita yang ada di masyarakat bisa belajar untuk membuat kerajinan yang bisa dipasarkan sebagai solusi peningkatan ekonomi dan pencegahan mantan TKW pergi keluar negeri pelatihan ini adalah alternatif sangat baik untuk dikembangangkan kepada masyarakat khususnya mantan TKW dan wanita dari masyarakat berpenghasilan rendah, dikarenakan kerajinan industry rumahan ini disamping memiliki nilai ekonomi, juga sangat diminati oleh berbagai kalangan dan dapat dikembangkan di daerah-daerah dengan melibatkan potensi SDM daerah sehingga menjadi suatu produk yang kompetitif.

Melalui pendekatan On the spot dan Bottom $U p$ serta aliansi strategi bersama dengan berbagai pihak yang terkait dalam pemberdayaan Wanita, kami optimis bahwa melalui program yang dilakukan ini akan terciptakan suatu kegiatan yang berhasil guna dan bernilai ekonomis.

Upaya untuk meningkatkan kehidupan yang lebih layak dan sejahtera tidak hanya melalui suatu pendidikan formal, melainkan dapat juga dikembangkan melalui jalur non formal yaitu Belajar Kecakapan Hidup (Life Skills Education). Namun pokok persoalan dari seluruh permasalahan adalah bagaimana menempatkan masyarakat yang tidak memiliki kesempatan untuk berpendidikan tinggi dapat diberdayakan (empowering) sehingga memiliki keterampilan agar bisa menambah penghasilannya.

Salah satu alternatif adalah melalui Pelatihan Keterampilan Kerajinan industi rumahan ini bisa berupa dompet, tas, tempat pensil, sajadah dan lain sebagainya, yang bisa dijadikan souvenir. Beberapa hal yang melatarbelakangi alternatif ini adalah sebagai industri rumahan/ souvenir adalah produk yang prosesnya pengerjaannya sebagian besar $(80 \%)$ menggunakan limbah plastik.

Industri rumahan ini memiliki keunikan, yaitu sangat unik untuk dipelajari dan diperdalam karena memiliki kemungkinan kreasi yang tidak terbatas, tergantung dari kreatifitas pembuat. Produk Industri rumahan ini memiliki segmen pasar yang spesifik dan apresiasi produk begitu tinggi sebagai barang seni. 
Produk Industri rumahan ini memiliki alternatif yang luas dari segi aplikasi dan estetika, diantaranya adalah: tas, dompet, tikar, tempat pensil dan masih banyak perlatan yang munkin bisa dibuat dari limbah plastik ini. Dapat memberi kesempatan kepada mantan tenaga kerja wanita dan ibu rumah tangga dalam memanfaatkan waktu diluar kegiatan mengurus rumah tangga ke hal-hal produktif dan menghasilkan.

Pelatihan kerajinan ini sekaligus untuk menciptakan lapangan kerja baru. Diharapkan setelah mendapat proses pelatihan, dukungan dan pendampingan hingga mampu memproduksi barang jadi kerajinan kain perca, diharapkan akan terbentuk suatu Kelompok Swadaya Masyarakat yang produktif.

\section{B. PERMASALAHAN}

Dari latar belakang yang sudah dikemukan tersebut di atas, akan menimbulkan rumusan masalah sebagai berikut :

"Bagaimana memberdayakan mantan TKW, wanita usia produktif, dan wanita pengangguran untuk menambah penghasilan dan meningkatkan ekonomi keluarga melalui pemanfaatkan limbah plastik?"

\section{TUJUAN KEGIATAN}

Adapun tujuan dari kegiatan pemberdayaan ini adalah sebagai berikut:

1. Memberikan suatu keterampilan membuat kerajinan dari sampah bungkus plastik.

2. Memberikan suatu keterampilan yang bisa bermanfaat secara pribadi yang memiliki nilai jual.

3. Memberdayakan perempuan untuk lebih terampil, dapat berkarya dan menghasilkan suatu produk yang memiliki nilai jual.

4. Menciptakan sinergi yang kuat atas peran serta usaha dan pemerintah mengatasi dampak krisis selama ini.

\section{MANFAAT KEGIATAN}

Manfaat dari kegiatan ini akan mempunyai dampak jangka pendek dan jangka panjang sebagai berikut :

\section{Jangka pendek}

1. Dapat menghimpun peserta pelatihan yang dianggap siap dan mampu menerima proses pengembangan diri, khususnya adalah mantan TKW dan wanita masyarakat berpenghasilan rendah atau komunitas masyarakat usia kerja yang masih menganggur.

2. Peserta mampu menghasilkan produk yang dapat diserap oleh pembeli dan akan menjadi contoh (ditiru) sehingga menyebar kepada masyarakat lainnya. Kondisi ini diharapkan akan memacu peserta lainnya untuk mengembangkan dan menciptakan produkproduk kerajinan souvenir.

Apresiasi dan perilaku peserta meningkat serta berorientrasi pada peningkatan taraf kehidupan.

\section{Jangka Panjang :}

1. Dapat tercipta kelompok Swadaya Masyarakat (komunitas) yang berprofesi sebagai pengrajin indutri rumahan.

2. Dapat terjalin kemitraan antara peserta yang berperan sebagai pengrajin baru dan Lembaga usaha berperan sebagai fungsi pemasaran produk kerajinan industri rumahan.

3. Dapat menciptakan lahan nafkaf sebagai peningkatan ekonomi keluarga.

\section{KAJIAN TEORETIK}

\section{A. PENGERTIAN PEMBERDAYAAN MASYARAKAT}

Secara konseptual pemberdayaan atau pemberkuasaan (empowerment) berasal dari kata power (kekuasaan atau keberdayaaan), karena ide utama pemberdayaan bersentuhan dengan konsep mengenai kekuasaan. Kekuasaan seringkali dikaitkan dengan kemampuan kita untuk membuat orang lain melakukan apa yang kita inginkan, terlepas dari keinginan dan niat mereka. Ilmu sosial tradisional menekankan bahwa kekuasaan berkaitan dengan pengaruh dan kontrol.

Empowerment yang diterjemahkan dalam bahasa Indonesia berarti pemberdayaan adalah sebuah konsep yang lahir sebagai bagian dari perkembangan alam pikiran masyarakat dan kebudayaan barat utamanya Eropa. Untuk memahami konsep empowerment secara tepat dan jernih memerlukan upaya pemahaman latar belakang kontekstual yang melahirkannya, 
menurut merriam webster dan oxfort english dictionery (dalam prijono dan pranarka, 1996: 3) mengandung dua pengertian yaitu: pengertian pertama adalah to give power or authority to, dan pengertian kedua berarti to give ability to or enable. dalam pengertian pertama diartikan sebagai memberi kekuasaan, mengalihkan kekuatan atau mendelegasikan otoritas ke pihak lain. sedang dalam pengertian kedua, diartikan sebagai upaya untuk memberikan kemampuan atau keberdayaan.

Konsep empowerment pada dasarnya adalah upaya menjadikan suasana kemanusiaan yang adil dan beradab menjadi semakin efektif secara struktural, baik dalam kehidupan keluarga, masyarakat, negara, regional, internasional, maupun dalam bidang politik, ekonomi dan lain-lain. memberdayakan masyarakat, Pemberdayaan menurut Suhendra (2006:74-75) adalah "suatu kegiatan yang berkesinambungan, dinamis, secara sinergis mendorong keterlibatan semua potensi yang ada secara evolutif dengan keterlibatan semua potensi”.

Selanjutnya pemberdayaan menurut Ife (dalam Suhendra, 2006:77) adalah "meningkatkan kekuasaan atas mereka yang kurang beruntung (empowerment aims to increase the power of disadvantage)".

Sedangkan menurut Widjaja (2003:169) pemberdayaan masyarakat adalah upaya meningkatkan kemampuan dan potensi yang dimiliki masyarakat, sehingga masyarakat dapat mewujudkan jati diri, harkat dan martabatnya secara maksimal untuk bertahan dan mengembangkan diri secara mandiri baik di bidang ekonomi, sosial, agama dan budaya. Adapun menurut kartasasmita (1996: 144) adalah upaya untuk meningkatkan harkat dan martabat lapisan masyarakat yang dalam kondisi sekarang tidak mampu untuk melepaskan diri dari perangkap kemiskinan dan keterbelakangan.

Pemberdayaan masyarakat merupakan sebuah konsep pembangunan ekonomi yang merangkum nilai-nilai sosial. konsep ini mencerminkan paradigma baru pembangunan, yakni yang bersifat "people-centered, participatory, empowering, and sustainable gagasan pembangunan yang mengutamakan pemberdayaan masyarakat perlu untuk dipahami sebagai suatu proses transformasi dalam hubungan sosial, ekonomi, budaya, dan politik masyarakat. perubahan struktur yang sangat diharapkan adalah proses yang berlangsung secara alamiah, yaitu yang menghasilkan dan harus dapat dinikmati bersama. begitu pula sebaliknya, yang menikmati haruslah yang menghasilkan. proses ini diarahkan agar setiap upaya pemberdayaan masyarakat dapat meningkatkan kapasitas masyarakat (capacity building) melalui penciptaan akumulasi modal yang bersumber dari surplus yang dihasilkan, yang mana pada gilirannya nanti dapat pula menciptakan pendapatan yang akhirnya dinikmati oleh seluruh rakyat dan proses transpormasi ini harus dapat digerakan sendiri oleh masyarakat. menurut sumodiningrat (1999:134), mengatakan bahwa kebijaksanaan pemberdayaan masyarakat secara umum dapat dipilah dalam tiga kelompok yaitu: pertama, kebijaksanaan yang secara tidak langsung mengarah pada sasaran tetapi memberikan dasar tercapainya suasana yang mendukung kegiatan sosial ekonomi masyarakat. kedua, kebijaksanaan yang secara langsung mengarah pada peningkatan kegiatan ekonomi kelompok sasaran. ketiga, kebijaksanaan khusus yang menjangkau masyarakat miskin melalui upaya khusus. pelaksanaan pemberdayaan masyarakat,

Pemberdayaan masyarakat menurut kartasasmita (1996:159-160), harus dilakukan melalui beberapa kegiatan: pertama, menciptakan suasana atau iklim yang memungkinkan potensi masyarakat berkembang (enabling). kedua, memperkuat potensi atau daya yang dimiliki oleh masyarakat (empowering). ketiga, memberdayakan mengandung pula arti melindungi. di sinilah letak titik tolaknya yaitu bahwa pengenalan setiap manusia, setiap anggota masyarkat, memiliki suatu potensi yang selalu dapat terus dikembangkan. artinya, tidak ada masyarakat yang sama sekali tidak berdaya, karena kalau demikian akan mudah punah.

Pemberdayaan merupakan suatu upaya yang harus diikuti dengan tetap memperkuat potensi atau daya yang dimiliki oleh setiap masyarakat. dalam rangka itu pula diperlukan langkah-langkah yang lebih positif selain dari menciptakan iklim dan suasana. perkuatan ini meliputi langkahlangkah nyata dan menyangkut penyediaan berbagai masukan (input) serta membuka akses kepada berbagai peluang (upportunities) yang nantinya 
dapat membuat masyarakat menjadi semakin berdaya.

Menurut Adisasmita (2006:35)" Pemberdayaan masyarakat adalah upaya pemanfaatan dan pengelolaan sumber daya masyarakat pedesaan yang lebih efektif dan efesien, seperti:

1. Aspek masukan atau input

Seperti Sumber Daya Manusia (SDM) dana, peralatan atau sarana, data, rencana, teknologi.

2. Aspek proses

Seperti pelaksanaan, monitoring dan pengawasan.

3. Aspek keluaran dan out put

Seperti pencapaian sasaran, efektivitas dan efisiensi.

Menurut Sumaryadi (2005:11) pemberdayaan masyarakat adalah "upaya mempersiapkan masyarakat seiring dengan langkah upaya memperkuat kelembagaan masyarakat agar mereka mampu mewujudkan kemajuan, kemandirian, dan kesejahteraan dalam suasana keadilan sosial yang berkelanjutan". Selain itu pemberdayaan masyarakat menurut Sumaryadi juga pada dasarnya sebagai berikut:

1. Membantu pengembangan manusiawi yang autentik dan integral dari masyarakat lemah, rentan, miskin perkantoran, masyarakat adat yang terbelakang, kaum muda pencari kerja, kaum cacat dan kelompok wanita yang didiskriminasikan/dikesampingkan.

2. Memberdayakan kelompok - kelompok masyarakat tersebut secara sosial ekonomis sehingga mereka dapat lebih mandiri dan dapat memenuhi kebutuhan dasar hidup mereka, namun sanggup berperan serta dalam pengembangan masyarakat. Dari pendapat tersebut maka, pemberdayaan masyarakat adalah upaya untuk meningkatkan harkat dan martabat lapisan masyarakat yang dalam kondisi sekarang tidak mampu melepaskan diri dari perangkap kemiskinan dan keterbelakangan.

Sedangkan menurut Prijono dan Pranaka (1996:105-106) mengemukakan bahwa pemberdayaan masyarakat harus dilakukan melalui tiga cara, yaitu:
1. Menciptakan suasana atau iklim yang memungkinkan potensi masyarakat untuk berkembang kondisi ini berdasarkan asumsi bahwa setiap individu dan masyarakat memiliki potensi untuk mengorganisasi dirinya sendiri dan potensi kemandirian tiap individu perlu diberdayakan. Proses pemberdayaan masyarakat berakar kuat pada proses kemandirian tiap individu, yang kemudian meluas ke keluarga, serta kelompok masyarakat baik di tingkat lokal maupun nasional.

2. Memperkuat potensi atau daya yang dimiliki oleh masyarakat dengan menerapkan langkahlangkah nyata, menampung berbagai masukan, menyediakan prasarana baik fisik (irigasi, jalan,dan listrik) maupun sosial (sekolah dan fasilitas pelayanan kesehatan) yang dapat diakses oleh masyarakat lapisan paling bawah. Terbentuknya akses pada berbagai peluang akan membuat masyarakat semakin berdaya, seperti tersedianya lembaga-lembaga pendanaan, pelatihan, dan pemasaran di pedesaan, dalam upaya memberdayakan masyarakat ini yang penting antara lain adalah peningkatan mutu dan perbaikan sarana pendidikan dan kesehatan serta akses pada sumber-sumber kemajuan ekonomi seperti modal, teknologi, informasi, lapangan kerja, dan pasar.

3. Memberdayakan masyarakat dalam arti melindungi dan membela kepentingan masyarakat lemah. Dalam proses pemberdayaan harus dicegah jangan sampai yang lemah bertambah lemah atau makin terpinggirkan dalam menghadapi yang kuat. Oleh karena itu, perlindungan dan pemihakan kepada yang lemah amat mendasar sifatnya dalam konsep pemberdayaan masyarakat. Melindungi dan membela harus dilihat sebagai upaya untuk mencegah terjadinya persaingan yang tidak seimbang dan eksploitasi atas yang lemah.

Berdasarkan pada beberapa konsep diatas, maka dapat disimpulkan bahwa pemberdayaan adalah upaya membangun daya itu untuk mendorong (Encourage), memotivasi dan membangkitkan kesadaran dan dapat dijelaskan bahwa pemberdayaan masyarakat 
berarti meningkatkan kemampuan atau meningkatkan kemandirian masyarakat dari yang kurang berdaya menjadi lebih berdaya, bukan membuat masyarakatnya menjadi tergantung pada berbagai program pembangunan yang ada, tetapi yang harus dihasilkan dan dinikmati atas hasil usaha sendiri.

Selain itu upaya memberdayakan masyarakat dapat dilakukan melalui tiga cara, yaitu yang memungkinkan potensi masyarakat untuk berkembang. Memperkuat potensi atau daya yang dimiliki, dan memberdayakan masyarakat dalam arti melindungi dan membela kepentingan masyarakat lemah. Pemberdayaan bukan hanya meliputi individu-individu dalam masyarakat saja, tetapi juga unsurunsur pranata penduduknya. Misalnya, nilainilai modern, kerja keras, hemat, kemerdekaan, rasa tanggung jawab dan sebagainya. Demikian pula dengan pembaharuan lembagalembaga sosial dan pengintegrasiannya kedalam kegiatan-kegiatan pembangunan serta kegiatan pembangunan serta peranan masyarakat didalamnya.

\section{B. PENGERTIAN LIMBAH PLASTIK}

Plastik adalah senyawa polimer alkena dengan bentuk molekul sangat besar. Molekul plastik terbentuk dari kondensasi organik atau penambahan polimer dan bisa juga terdiri dari zat lain untuk meningkatkan performa atau nilai ekonominya. Istilah plastik, menurut pengertian kimia, mencakup produk polimerisasi sintetik atau semisintetik. Molekul plastik terbentuk dari kondensasi organik atau penambahan polimer dan bisa juga terdiri dari zat lain untuk meningkatkan performa atau nilai ekonominya. Secara alamiah, terdapat beberapa polimer (pengulangan tidak terhingga dari monomer-monomer) yang digolongkan ke dalam kategori plastik. Secara fisik, plastik bisa dibentuk atau dicetak menjadi lembar film atau serat sintetik, yang disebabkan karena plastik juga bersifat "malleable" alias memiliki sifat bisa dibentuk atau ditempa. Dalam proses industri dan pabrikasi, plastik dibuat dalam jenis yang sangat banyak. Sifat-sifat bisa menerima tekanan, panas, keras juga lentur, dan bisa digabung dengan partikel lain semisal karet, metal, dan keramik. Sehingga wajar jika plastik bisa dipergunakan secara massa untuk banyak sekali keperluan. Bahkan keranjang belanja yang umum dibawa ibu-ibu ke pasar juga kini diganti plastik kresek yang berubah menjadi sampah begitu sampai di rumah

\section{SIFAT DAN JENIS PLASTIK}

Plastik memiliki banyak sifat istimewa, sehingga dapat digunakan untuk berbagai keperluan, antara lain:

1. Mudah dibentuk menjadi berbagai macam bentuk.

2. Tahan lama dan tidak berkarat.

3. Relatif murah.

Namun demikian, bahan kimia ini juga memiliki beberapa kelemahan, diantaranya:

1. Mudah terbakar sehingga beresiko jika digunakan dalam kendaraan bermotor atau bagian bagian rumah. Untuk mengatasi sifat mudah terbakar ini, maka berbagai barangplastik seperti furnitur, dilapisi dengan bahan yang tahan api yang disebut retardan.

2. Jika terbakar menghasilkan gas-gas racun, diantaranya karbon monoksida. Sering kali uap beracun ini lebih berbahaya daripada panas yang dihasilkan.

3. Plastik bukan saja tahan karat, tetapi juga sukar diuraikan oleh mikroorganisme (nonbiodegradable). Oleh karena itu, limbah plastik menjadi masalah lingkungan menyebabkan pencemaran pandangan dan pencemaran tanah. Sampah plastik dapat pula menahan menahan air, sehingga menjadi media perkembangan nyamuk. Untuk mengatasi hal ini, para hali berupaya membuat plastik ramah lingkungan, yaitu plastik yang dapat terurai.

4. Kelemahan lainnya adalah karena bahan kimia ini dibuat dari bahan baku minyak bumi dan gas alam. Seperti yang diketahui bahwa minyak bumi dan gas alam merupakan sumber daya alam yang tidak dapat diperbaharui, sehingga suatu saat akan habis. Hal ini merupakan tantangan bagi para ahli untuk menemukan pengganti plastik. 
Plastik merupakan jenis monomer yang dapat dimodifikasi maka jenis plastik juga sangat beragam. Dari jenis monomer dapat pula dibentuk berbagai macam plastik bergantung pada panjangnya rantai atau kerapatan antar molekulnya. Selain itu, satu plastik dapat juga merupakan gabungan dari dua atau lebih macam monomer dengan perbandingan yang dapat berbeda pula, misalnya, dua jenis monomer, misalnya A dan B, dapht hrtpsilbdntiolkg/10 berbagai macam kombinasi, seperti $\mathrm{A}-\mathrm{B}-\mathrm{A}-\mathrm{B}$ atau $\mathrm{A}-\mathrm{A}-\mathrm{B}-\mathrm{B}-\mathrm{A}-\mathrm{A}-$, dan sebagainya. Dewasa ini, ribuan jenis plastik telah berhasil dibuat. Berikut ini dibahas beberapa jenis plastik yang benyak digunakan.

\section{POLIETILENA}

Polietilena merupakan plastik yang paling banyak diproduksi. Plastik ini digunakan antara lain untuk membuat plastik lembaran, kantong plastik, botol plastik, dan pembungkus kabel.

\section{POLIVINILKLORIDA (PVC)}

PVC merupakan plastik kedua yang paling banyak dari segi jumlah produksi. Monomer penyusunnya berupa vinilklorida $(\mathrm{CH} 2=\mathrm{CHCl})$. Plastik ini digunakan antara lain untuk membuat pipa, pelapis lantai, dan selang.

\section{POLIPROPILENA}

Polipropilena dibuat dari monomer propilena $(\mathrm{CH} 3-\mathrm{CH}=\mathrm{CH} 2)$. Plastik ini lebih kuat dari pada polietilena, sehingga digunakan antara lain untuk membuat karung, tali, dan botol.

\section{TEFLON ATAU \\ POLITETRAFLUOROETILENA (PTFE)}

Teflon merupakan plastik yang sangat kuat, tidak reaktif dan tahan panas. Plastik jenis ini digunakan sebagai pelapis tangki di pabrik kimia dan pada panci anti lengket.

\section{POLIVINIL ASETAT (PVA)}

PVA adalah plastik yang dapat menyerap air jauh lebih banyak dari pada massanya sendiri. Monomer penyusunnya berupa vinilasetat $(\mathrm{CH} 2=\mathrm{CHOH})$. Plastik ini digunakan antara lain untuk membuat popok bayi.

\section{LIMBAH PLASTIK YANG DALAM PEMBUATAN SOUVENIR}

Pembuatan souvenir atau industri rumahan yang berbahan dasr plastic tentu tidak menggunakan sembanrang plastik, adapun plastik limbah yang digunakan untuk industri kerajinan rumahan adalah jenis Polietilena yang merupakan plastik paling banyak diproduksi. Plastik limbah yang oldgyamalstanta alababibungkus kopi permen, bungkus minuman atau makanan instant, bungkus deterjen dan bungkus-bungkus lain yang bisa dimanfaatkan untuk kerajinan industri rumahan.

\section{TEKNIS PELAKSANAAN KEGIATAN \\ A. METODE PEMECAHAN MASALAH (PROBLEM SOLVING METHOD)}

Metode pemecahan masalah (problem solving) adalah penggunaan metode dalam sebuah kegiatan dengan jalan melatih seseorang menghadapi berbagai masalah baik itu masalah pribadi atau perorangan maupun masalah kelompok untuk dipecahkan sendiri atau secara bersama-sama.

Penyelesaian masalah merupakan proses dari menerima tantangan dan usaha - usaha untuk menyelesaikannya sampai menemukan penyelesaiannya. menurut Syaiful Bahri Djamara (2006 : 103) bahwa:

Metode problem solving (metode pemecahan masalah) bukan hanya sekedar metode tetapi juga merupakan suatu metode berfikir, sebab dalam problem solving dapat menggunakan metode lain yang dimulai dari mencari data sampai kepada menarik kesimpulan.

Menurut N. Sudirman (1987:146) metode problem solving adalah cara penyajian bahan atau materi dengan menjadikan masalah sebagai titik tolak pembahasan untuk dianalisis dan disintesis dalam usaha untuk mencari pemecahan atau jawabannya oleh seseorang. Sedangkan menurut Gulo (2002:111) menyatakan bahwa problem solving adalah metode yang mengajarkan penyelesaian masalah dengan memberikan penekanan pada terselesaikannya suatu masalah secara menalar.

Senada dengan pendapat diatas Sanjaya (2006:214) menyatakan pada metode pemecahan masalah, materi tidak terbatas pada referensi saja tetapi juga bersumber dari peristiwa - peristiwa tertentu sesuai dengan cara yang berlaku. 
Dari pendapat di atas maka dapat disimpulkan metode problem solving adalah suatu penyajian materi atau bahan yang menghadapkan pada persoalan yang harus dipecahkan atau diselesaikan untuk mencapai tujuan. Dalam pemberdayaan ini di haruskan melakukan penyelidikan otentik untuk mencari penyelesaian terhadap masalah yang diberikan. Mereka menganalisis dan mengidentifikasikan masalah, mengembangkan hipotesis, mengumpulkan dan menganalisis informasi dan membuat kesimpulan.

Langkah - Langkah Metode Pemecahan Masalah (Problem Solving Method). Penyelesaian masalah menurut J. Dewey dalam bukunya W.Gulo (2002:115) dapat dilakukan melalui enam tahap yaitu:

\begin{tabular}{|c|c|}
\hline Tahap - Tahap & $\begin{array}{c}\text { Kemampuan } \\
\text { yang diperlukan }\end{array}$ \\
\hline $\begin{array}{l}\text { 1) Merumuskan } \\
\text { masalah }\end{array}$ & $\begin{array}{l}\text { Mengetahui dan } \\
\text { masalah merumuskan } \\
\text { secara jelas }\end{array}$ \\
\hline 2) Menelaah masalah & $\begin{array}{l}\text { Menggunakan } \\
\text { pengetahuan untuk } \\
\text { memperinci } \\
\text { menganalisa masalah } \\
\text { dari berbagai sudut }\end{array}$ \\
\hline $\begin{array}{l}\text { 3) Merumuskan } \\
\text { hipotesis }\end{array}$ & $\begin{array}{l}\text { Berimajinasi dan } \\
\text { menghayati ruang } \\
\text { lingkup, sebab - } \\
\text { akibat dan alternative } \\
\text { penyelesaian }\end{array}$ \\
\hline $\begin{array}{l}\text { 4) Mengumpulkan } \\
\text { dan mengelompok- } \\
\text { kan data sebagai } \\
\text { bahan pembuktian } \\
\text { hipotesis }\end{array}$ & $\begin{array}{l}\text { Kecakapan mencari } \\
\text { dan menyusun data } \\
\text { menyajikan data } \\
\text { dalam bentuk } \\
\text { diagram,gambar } \\
\text { dan tabel }\end{array}$ \\
\hline $\begin{array}{l}\text { 5) Pembuktian } \\
\text { hipotesis }\end{array}$ & $\begin{array}{l}\text { Kecakapan menelaah } \\
\text { dan membahas data, } \\
\text { kecakapan meng- } \\
\text { hubung - hubungkan } \\
\text { dan menghitung } \\
\text { keterampilan } \\
\text { mengambil keputusan } \\
\text { dan kesimpulan }\end{array}$ \\
\hline
\end{tabular}

\begin{tabular}{|l|l|}
\hline $\begin{array}{l}\text { 6) Menentukan } \\
\text { pilihan } \\
\text { penyelesaian }\end{array}$ & $\begin{array}{l}\text { Kecakapan membuat } \\
\text { altenatif penyelesaian }\end{array}$ \\
& $\begin{array}{l}\text { kecakapan dengan } \\
\text { memperhitungkan } \\
\text { akibat yang terjadi } \\
\text { pada setiap pilihan }\end{array}$ \\
\hline
\end{tabular}

Berpijak pada rumusan di atas, Pelatihan yang diadakan sebagai salah salah pemberdayaan wanita usia produktif, mantan TKW, dan pengangguran dimulai dari perumusan masalah yang terjadi di wilayah tempat kegiatan, dengan mengetahui kondisi dan keadaan yang mungkin bisa diciptakan dengan merumuskan masalah secara jelas.

Perumusan masalah yang sudah dirumuskan ditelaah dengan mempertimbangkan aspek yang timbul bila akan diadakan tindakan untuk mengatasi masalah tersebut, yang kemudian mengadakan hipotesa-hipotesa yang bisa dijadikan dugaan sementara kalau kegiatan pemberdayaan itu dilakukan.

Sebagai langkah selanjutnya, untuk membuktikan hipotesa itu dilakukan ujicoba sampel melalui wawancara terhadap objek peserta dengan melatih keterampilan pembuatan souvenir yang bisa dijual, dan ternyata dapat sambutan dari pemerintah desa untuk melanjutkan kegiatan pemberdayaan wanita ini di skala yang lebih besar, bahkan bisa dijadikan salah satu program kerja kerja pemerintah desa.

Untuk menyambut keinginan pemerintah desa ini maka diadakanlah pelatihan pemberdayaan wanita usia produktif, TKW, dan pengangguran yang bekerja sama dengan Lembaga Pengambdian Kepada Masyarakat Universitas Negeri Jakarta (LPM UNJ), sebagai usaha mengatasi masalah yang ada di wilayah Desa Rowokembu, Kecamatan Wonopringgo Pekalongan, untuk membantu mencari solusi alternatif sampingan dalam meningkatkan taraf ekonomi bagi warga di wilayah tersebut.

\section{B. KHALAYAK SASARAN}

Sasaran Peserta yang diutamakan dalam kegiatan ini adalah :

1. Mantan TKW

2. Remaja Putus Sekolah/wanita usia produktif 
3. Masyarakat Belum bekerja atau pengangguran

Dengan pertimbangan efektifitas proses dan metode pengembangan, direncanakan peserta pelatihan yang terlibat dalam program berjumlah 20 orang pertahapan. Prospek dari kegiatan diharapkan akan memberikan kesempatan yang lebih luas dalam pemasaran, produk, dan SDM.

\section{1) PEMASARAN}
a. Pasar bisa relatif terbuka
b. Harga jual relatif bersaing
c. Pemasaran On line

\section{2) PRODUK}

a. Diferensiasi produk menggunakan sampah plastik bungkus makanan, minuman, atau bekas bungkus sabun cuci

b. Apresiasi pasar terhadap produk tinggi

\section{3) SDM}

Dapat menyerap tenaga kerja mantan TKW dan masyarakat berpendidikan rendah khususnya wanita namun memiliki keterampilan membuat kerajinan indutri rumahan berupa souvenir ataupun barang yang mempunyai nilai jual yang dapat dijadikan sebagai mata pencaharian tambahan.

\section{WAKTU DAN TEMPAT}

Pelaksanaan kegiatan ini dilakukan mulai tanggal 26 Agustus sampai 2 September 2016 yang dibuka dan ditutup kegiatan ini di Balai Desa Rowokembu Kecamatan Wonopringgo Pekalongan, adapun pelaksanaan kegiatan dilakukan dengan cara pelatihan mandiri dan berkelompok secara tutorial langsung dari instruktur yang mendampinginya di salah satu rumah warga peserta pelatihan, Hal ini dilakukan agar waktu dan semangat peserta untuk menyelesaikan pekerjaan bisa tercapai.

\section{PELAKSANAAN KEGIATAN}

A. KERANGKA PEMECAHAN MASALAH

Untuk mewujudkan pelaksanaan kegiatan yang sudah melalui studi lapangan dan perumusan masalah, penyelenggara berusaha membuat kerangka pemecahan masalah dengan memetakan unsur-unsur yang mendukung kegiatan pemberdayaan antara lain, pihak yang terlibat, pembiayaan program, dan kurikulum atau panduan kegiatan seperti di bawah ini

\section{Pihak Yang terlibat Program}

1. UPT LPM UNJ

2. Pemerintah kota/daerah melalui instansi yang terkait

3. Masyarakat daerah yang dikembangkan

\section{Pembiayaan Program}

1. Anggaran Program,

2. Rincian Anggaran Proses Pelatihan

3. Rincian Anggaran Peralatan dan Perlengkapan

4. Rincian Manajemen pelaksanaan dan evslusi kegiatan

5. Proses kegiatan

a. Strategi Penguatan dan Pengembangan

b. Konsep Metodelogi penguatan dan Pengembangan

c. Evaluasi

\section{Panduan atau Kurikulum Kegiatan}

Untuk mendukung keberhasilan kegiatan pemberdayaan ini diperlukan

1. Materi Pelatihan

2. Bahan baku dasar

3. Waktu

4. Keterangan
a. Pengenalan Kerajinan industri rumahan
b. Pengenalan alat
c. Pemahaman bahan Baku
d. Pemahaman pola \& bentuk produk
e. Tata cara memulai produk

5 Praktek
a. Pengumpulan bahan dasar
b. Pemilahan bahan dasar
c. Gambar bentuk dasar yang dibuat
d. Mengukur ukuran bahan dasar
e. Menggunting dan melipat sesuai ukuran
f. Memola lipatan plastik
g. Menjahit hasil
h. Menyusun bahan dan menambah assesoris
i. Membentuk Produk
j. menyelesaikan produk (finishing)
k. Memeriksa pekerjaan
1. Siap dipajang dan dijual 
Itulah kerangka pemecahan masalah dalam kegiatan pemberdayan mantan wanita usia produktif di Wilayah Wonopringgo Kabupaten Pekalongan.

\section{B. ALUR KEGIATAN}

Pelaksanaan kegiatan pemberdayaan ini mulai tanggal 26 Agustus 2016 yang bertempat di Balai Desa Rowokembu Kecamatan Wonopringgo Pekalongan, pada kegiatan ini dibuka secara resmi oleh Kepala Desa Rowokembu dan disaksikan dari aparat Kecamatan Wonopringgo, perwakilan pengurus $\mathrm{PKK}$, perwakilan pengurus BKM, perwakilan BPD, Instruktur dan peserta pelatihan.

Kegiatan sengaja mengundang dari seluruh elemen kemasyaratakan agar kegiatan ini bisa dijadikan kegiatan lanjutan oleh pemerintah desa sebagai salah satu program yang dibiayai oleh pemerintah desa. Sehingga pemerintah desa ikut berperan serta dalam penanggulangan pengangguran dan bisa menjadi media pengurangan arus balik TKW ke luar negeri.

Kegiatan ini dihadiri dari sekitar 27 orang yang terdiri dari 5 warga elemen masyarakat, 2 orang instruktur, dan 20 peserta pelatihan.

\section{PELAKSANAAN KEGIATAN}

\section{A. KONSEP DASAR PEMANFAATAN LIMBAH}

Untuk pemanfaatan limbah perlu dilihat dari keterkaitan terbentuknya limbah, khususnya limbah padat, ada 2 (dua) pendekatan yang dapat dilakukan untuk mengendalikan akibat adanya limbah, yaitu:

a. Pendekatan proaktif: yaitu upaya agar dalam proses penggunaan bahan akan dihasilkan limbah yang seminimal mungkin, dengan tingkat bahaya yang serendah mungkin.

b. Pendekatan reaktif: yaitu penanganan limbah yang dilakukan setelah limbah tersebut terbentuk Pendekatan proakatif merupakan strategi yang diperkenalkan pada akhir tahun 1970-an dalam dunia industri, dikenal sebagai proses bersih atau teknologi bersih yang bersasaran pada pengendalian atau reduksi terjadinya limbah melalui penggunaan teknologi yang lebih bersih dan yang akrab lingkungan.
Konsep ini secara sederhana melingkupi:

a) Pengaturan yang lebih baik dalam manajemen penggunaan bahan dan enersi serta limbahnya melalui good house keeping

b) Penghematan bahan baku, fluida dan enersi yang digunakan

c) Pemakaian kembali bahan baku tercecer yang masih bisa dimanfaatkan

d) Penggantian bahan baku, fluida dan enesi

e) Pemodivikasian proses bahkan kalau perlu penggantian proses dan teknologi yang digunakan agar emisi atau limbah yang dihasilkan seminimal mungkin dan dengan tingkat bahaya yang serendah mungkin

f) Pemisahan limbah yang terbentuk berdasarkan jenisnya agar lebih mudah penanganannya

Adapun pendekatan reaktif, yaitu konsep yang dianggap perlu diperbaiki, adalah konsep dengan upaya pengendalian yang dilakukan setelah limbah terbentuk, dikenal sebagai pendekatan end of $\neg$ pipe. Konsep ini mengandalkan pada teknologi pengolahan dan pengurugan limbah, agar emisi dan residu yang dihasilkan aman dilepas kembali ke lingkungan. Konsep pengendalian limbah secara reaktif tersebut kemudian diperbaiki melalui kegiatan pemanfaatan kembali residu atau limbah secara langsung (reuse), dan/atau melalui sebuah proses terlebih dahulu sebelum dilakukan pemanfaatan (recycle) terhadap limbah tersebut.

Akibat dari semakin bertambahnya tingkat konsumsi masyarakat serta aktivitas lainnya maka bertambah pula buangan/limbah yang dihasilkan. Limbah/buangan yang ditimbulkan dari aktivitas dan konsumsi masyarakat sering disebut limbah domestik atau sampah. Limbah tersebut menjadi permasalahan lingkungan karena kuantitas maupun tingkat bahayanya mengganggu kehidupan makhluk hidup lainnya. Selain itu aktifitas industri yang kian meningkat tidak terlepas dari isu lingkungan. Industri selain menghasilkan produk juga menghasilkan limbah. Dan bila limbah industri ini dibuang langsung ke lingkungan akan menyebabkan terjadinya pencemaran lingkungan.

Limbah adalah buangan yang dihasilkan dari suatu proses produksi baik industri maupun domestik (rumah tangga, yang lebih dikenal 
sebagai sampah), yang kehadirannya pada suatu saat dan tempat tertentu tidak dikehendaki lingkungan karena tidak memiliki nilai ekonomis. Jenis limbah pada dasarnya memiliki dua bentuk yang umum yaitu; padat dan cair, dengan tiga prinsip pengolahan dasar teknologi pengolahan limbah.

Limbah dihasilkan pada umumnya akibat dari sebuah proses produksi yang keluar dalam bentuk \%scrapt atau bahan baku yang memang sudah bisa terpakai. Dalam sebuah hukum ekologi menyatakan bahwa semua yang ada di dunia ini tidak ada yang gratis. Artinya alam sendiri mengeluarkan limbah akan tetapi limbah tersebut selalu dan akan dimanfaatkan oleh makhluk yang lain. Prinsip ini dikenal dengan prinsip Ekosistem (ekologi sistem) dimana makhluk hidup yang ada di dalam sebuah rantai pasok makanan akan menerima limbah sebagai bahan baku yang baru.

Nama plastik mewakili ribuan bahan yang berbeda sifat fisis, mekanis, dan kimia. Secara garis besar plastik dapat digolongkan menjadi dua golongan besar, yakni plastik yang bersifat thermoplastic dan yang bersifat thermoset. Thermoplastic dapat dibentuk kembali dengan mudah dan diproses menjadi bentuk lain, sedangkan jenis thermoset bila telah mengeras tidak dapat dilunakkan kembali. Plastik yang paling umum digunakan dalam kehidupan sehari-hari adalah dalam bentuk thermoplastic. Seiring dengan perkembangan teknologi, kebutuhan akan plastik terus meningkat. Data BPS tahun 1999 menunjukkan bahwa volume perdagangan plastik impor Indonesia, terutama polipropilena (PP) pada tahun 1995 sebesar 136.122,7 ton sedangkan pada tahun 1999 sebesar 182.523,6 ton, sehingga dalam kurun waktu tersebut terjadi peningkatan sebesar $34,15 \%$. Jumlah tersebut diperkirakan akan terus meningkat pada tahun-tahun selanjutnya. Sebagai konsekuensinya, peningkatan limbah plastikpun tidak terelakkan. Menurut Hartono (1998) komposisi sampah atau limbah plastik yang dibuang oleh setiap rumah tangga adalah $9,3 \%$ dari total sampah rumah tangga.

Plastik juga merupakan bahan anorganik buatan yang tersusun dari bahan-bahan kimia yang cukup berahaya bagi lingkungan. Limbah daripada plastik ini sangatlah sulit untuk diuraikan secara alami. Untuk menguraikan sampah plastik itu sendiri membutuhkan kurang lebih 80 tahun agar dapat terdegradasi secara sempurna. Oleh karena itu penggunaan bahan plastik dapat dikatakan tidak bersahabat ataupun konservatif bagi lingkungan apabila digunakan tanpa menggunakan batasan tertentu. Sedangkan di dalam kehidupan seharihari, khususnya kita yang berada di Indonesia, penggunaan bahan plastik bisa kita temukan di hampir seluruh aktivitas hidup kita. Padahal apabila kita sadar, kita mampu berbuat lebih untuk hal ini yaitu dengan menggunakan kembali (reuse) kantung plastik yang disimpan di rumah. Dengan demikian secara tidak langsung kita telah mengurangi limbah plastik yang dapat terbuang percuma setelah digunakan (reduce). Atau bahkan lebih bagus lagi jika kita dapat mendaur ulang plastik menjadi sesuatu yang lebih berguna (recycle). Bayangkan saja jika kita berbelanja makanan di warung tiga kali sehari berarti dalam satu bulan satu orang dapat menggunakan 90 kantung plastik yang seringkali dibuang begitu saja. Jika setengah penduduk Indonesia melakukan hal itu maka akan terkumpul $90 \times 125$ juta= 11250 juta kantung plastik yang mencemari lingkungan. Berbeda jika kondisi berjalan sebaliknya yaitu dengan penghematan kita dapat menekan hingga nyaris $90 \%$ dari total sampah yang terbuang percuma.

Pemanfaatan limbah plastik merupakan upaya menekan pembuangan plastik seminimal mungkin dan dalam batas tertentu menghemat sumber daya dan mengurangi ketergantungan bahan baku impor. Pemanfaatan limbah plastik dapat dilakukan dengan pemakaian kembali (reuse) maupun daur ulang (recycle). Di Indonesia, pemanfaatan limbah plastik dalam skala rumah tangga umumnya adalah dengan pemakaian kembali dengan keperluan yang berbeda, misalnya tempat cat yang terbuat dari plastik digunakan untuk pot atau ember. Sisi jelek pemakaian kembali, terutama dalam bentuk kemasan adalah sering digunakan untuk pemalsuan produk seperti yang seringkali terjadi di kota-kota besar.

Pemanfaatan limbah plastik dengan cara daur umumnya dilakukan oleh industri. Secara umum terdapat empat persyaratan agar suatu limbah plastik dapat diproses oleh suatu industri, antara lain limbah harus dalam bentuk tertentu sesuai kebutuhan (biji, pellet, serbuk, pecahan), limbah harus homogen, tidak terkontaminasi, serta 
diupayakan tidak teroksidasi. Untuk mengatasi masalah tersebut, sebelum digunakan limbah plastik diproses melalui tahapan sederhana, yaitu pemisahan, pemotongan, pencucian, dan penghilangan zat-zat seperti besi dan sebagainya. Terdapat hal yang menguntungkan dalam pemanfaatan limbah plastik di Indonesia dibandingkan negara maju. Hal ini dimungkinkan karena pemisahan secara manual yang dianggap tidak mungkin dilakukan di negara maju, dapat dilakukan di Indonesia yang mempunyai tenaga kerja melimpah sehingga pemisahan tidak perlu dilakukan dengan peralatan canggih yang memerlukan biaya tinggi. Kondisi ini memungkinkan berkembangnya industri daur ulang plastik di Indonesia.

Pemanfaatan plastik daur ulang dalam pembuatan kembali barang-barang plastik telah berkembang pesat. Hampir seluruh jenis limbah plastik (80\%) dapat diproses kembali menjadi barang semula walaupun harus dilakukan pencampuran dengan bahan baku baru dan additive untuk meningkatkan kualitas. Terdapat empat jenis limbah plastik yang populer dan laku di pasaran yaitu polietilena (PE), High Density Polyethylene (HDPE), polipropilena (PP), dan asoi.

Ada empat prinsip yang dapat digunakan dalam menangani maslah sampah ini. Ke empat prinsip tersebut lebih dikenal dengan nama $4 \mathrm{R}$ yang meliputi:

1. Reduce (Mengurangi); sebisa mungkin lakukan minimalisasi barang atau material yang kita pergunakan. Semakin banyak kita menggunakan material, semakin banyak sampah yang dihasilkan.

2. Reuse (Memakai kembali); sebisa mungkin pilihlah barang-barang yang bisa dipakai kembali. Hindari pemakaian barang-barang yang disposable (sekali pakai, buang). Hal ini dapat memperpanjang waktu pemakaian barang sebelum ia menjadi sampah.

3. Recycle (Mendaur ulang); sebisa mungkin, barang-barang yg sudah tidak berguna lagi, bisa didaur ulang. Tidak semua barang bisa didaur ulang, namun saat ini sudah banyak industri non-formal dan industri rumah tangga yang memanfaatkan sampah menjadi barang lain.
4. Replace (Mengganti); teliti barang yang kita pakai sehari-hari. Gantilah barang barang yang hanya bisa dipakai sekalai dengan barang yang lebih tahan lama. Juga telitilah agar kita hanya memakai barang-barang yang lebih ramah lingkungan, misalnya, ganti kantong keresek kitadengan keranjang bila berbelanja, dan jangan pergunakan styrofoam karena kedua bahan ini tidak bisa didegradasi secara alami.

Sedangkan menurut Syahputra pola yang dapat dipakai dalam penanggulangan sampah meliputi Reduce, Reuse, dan Recycle, dan Composting (3RC) yang merupakan dasar dari penanganan sampah secara terpadu. Reduce (mengurangi sampah) atau disebut juga precycling merupakan langkah pertama untuk mencegah penimbunan sampah; Reuse (menggunakan kembali) berarti menghemat dan mengurangi sampah dengan cara menggunakan kembali barang-barang yang telah dipakai. Apa saja barang yang masih bisa digunakan;

Recycle (mendaur ulang) juga sering disebut mendapatkan kembali sumberdaya (resource recovery), khususnya untuk sumberdaya alami. Mendaur ulang diartikan mengubah sampah menjadi produk baru, khususnya untuk barangbarang yang tidak dapat digunakan dalam waktu yang cukup lama, misalnya kertas, alumunium, gelas dan plastik. Langkah utama dari mendaur ulang ialah memisahkar sampah yang sejenis dalam satu kelompok.

Composting merupakan proses pembusukan secara alami dari materi organik, misalnya daun, limbah pertanian (sisa panen), sisa makanan dan lain-lain. Pembusukan itu menghasilkan materi yang kaya unsur hara, antara lain nitrogen, fosfor dan kalium yang disebut kompos atau humus yang baik untuk pupuk tanaman.

Itulah sekilah tentang bagaimana konsep pemanfaatan limbah sebagai usaha penyelamatn lingkungan dan sebagai alternative sampingan tambahan pendapatan ekonomi keluarga.

\section{B. PROSEDUR KEGIATAN}

Kegiatan dimulai dengan memberikan wacana pemanfaatan limbah plastik yang bisa digunakan sebagai penambah penghasilan dan 
usaha sampingan yang bisa dikerjakan dirumah. Wacana pemanfaatan limbah ini diwacanakan melalui film yang diputar di kegiatan PKK dan kegiatan kewanitaan lainnya. Pemutaran film ini sebagai usaha penyadaran masyarakat terhadap limbah plastik yang bisa dijadikan potensi pengembangan peningkatan ekonomi masyarakat.

Langkah selanjutnya yaitu mengadakan pelatihan pemanfaatan limbah plastik kepada para wanita mantan TKW dan wanita usia produktif yang menginginkan penghasilan tambahan sebagai pemberdayaan wanita di daerah yang tinggal di Desa Rowokembu Kecamatan Wonopringgo Kabupaten Pekalongan, pada kegiatan ini hanya mengundang 20 orang yang mendaftar untuk ikut kegiatan ini.

Kegiatan ini dilaksanakan yang dimulai pada Hari Jum'at tanggal 26 Agustus 2016 pada pukul 13.00 bertempat di aula Balai Desa Rowokembu Kecamatan Wonopringgo Kabupaten Pekalongan,

Kegiatan setelah resmi dibuka oleh Kepala Desa Rowokembu, langsung dilanjutkan dengan pemutaran teknik pembuatan souvenir atau hasil produksi lain yang diinginkan, pemutaran dimaksudkan sebagai arahan langkah-langkah awal sampai pembuatannya.

Setelah pemutaran film peserta dibagikan kertas fotokopi berisi petunjuk teknis pembuatan souvenir, dan langsung praktek dengan dipandu oleh 2 orang instruktur, satu memberikan contoh dan yang satu keliling memberi contoh secara langsung.

Setelah tahap awal yang dimulai dari pengumpulan plastik, pengelompokkan jenis bungkus plastik, pengguntingan sesuai ukuran dan dilanjutkan dengan pelipatan plastik yang kemudian dijepit dari semua hasil lipatan peserta pelatihan.

Karena terbatasnya waktu, tahap selanjutnya para peserta diizinkan pulang dengan membawa bahan plastik secukupnya sesuai motif dan jenis corak yang akan dijadikan PR.

Sebagai kelanjutan dari pekerjaan peserta pelatihan, para peserta diwajibkan datang ke rumah instruktur untuk melihat dan praktek pembuatan souvenir. Peserta pelatihan bisa datang sewaktuwaktu sesuai janji. Dari sini peserta pelatihan dapat PR lagi, sesuai tahapan yang sudah dikerjakan oleh peserta.
Pada hari penutupan tanggal 2 September 2016 peserta sudah menghasilkan beberapa produk dari yang sederhana sampai yang rumit dengan dibantu instruktur.

\section{DAYA DUKUNG DAN HAMBATAN}

Kegiatan ini sudah barang tentu mempunyai daya dukung dan hambatan yang cukup menantang, adapun daya dukung dan hambatan tersebut bisa datang dari faktor lingkungan dan SDM, itu antara lain:

1. Produksi limbah plastik dari rumah tangga

2. Produksi limbah plastik warung warung yang cukup banyak.

3. Penampungan produk yang akan dijual melalui instansi terkait yang disediakan oleh pemerintah daerah sebagai media promosi

Sedangkan hambatannya antara lain:

1. Tidak tersedianya para pengepul limbah plastik yang berminat

2. Pedangang warung umum langsung membuang limbahnya tanpa memilah dan memilih jenis limbahnya.

3. Pemasaran dari produk yang sudah dibuat kadang cenderung relatif lama.

4. Produsen souvenir kurang memahami pemasaran on line (daring)

\section{KESIMPULAN DAN SARAN}

\section{A. KESIMPULAN}

Kesimpulan dari kegiatan ini adalah sebagi usaha alternatif peningkatan ekonomi keluarga melalui pemanfaatan limbah plastik yang mempunyai tujuan program yang diharapkan, dengan kategori jangka pendek dan jangka panjang, yang antara lain

\section{Jangka pendek:}

1. Menghimpun peserta pelatihan yang dianggap siap dan mampu menerima proses pengembangan diri, khususnya adalah mantan TKW dan wanita masyarakat berpenghasilan rendah atau komunitas masyarakat usia kerja yang masih menganggur.

2. Peserta mampu menghasilkan produk yang dapat diserap oleh pembeli dan akan menjadi contoh (ditiru) sehingga menyebar kepada 
masyarakat lainnya. Kondisi ini diharapkan akan memacu peserta lainnya untuk mengembangkan dan menciptakan produk-produk kerajinan souvenir.

3. Apresiasi dan perilaku peserta meningkat serta berorientrasi pada peningkatan taraf kehidupan.

\section{Sedangkan Jangka Panjang :}

1. Tercipta kelompok Swadaya Masyarakat (komunitas) yang berprofesi sebagai pengrajin indutri rumahan.

2. Terjalin kemitraan antara peserta yang berperan sebagai pengrajin baru dan Lembaga berperan sebagai fungsi pemasaran produk kerajinan industri rumahan.

Demikian gambaran berpikir dan uraian penjelasan mengenai program belajar sebagai usaha pemberdayaan wanita mantan TKW, wanita usia produktif, dan masyarakat berpengasilan rendah di desa Rowokembu Kecamatan Wonopringgo kabupaten Pekalongan Jawa Tengah.

\section{B. SARAN}

Kegiatan pelatihan sebagai usaha pemberdayaan wanita usia produktif ini, penyelenggara memberikan saran saran sebagi berikut:

1. Kegiatan seperti pemeberdayaan ini dapat dilakukan melalui perencanaan pembangunan di desa hendaknya dengan memperhatikan masalah yang dihadapi warga dari semua sektor yang meliputi epoleksosbudhankam yang seimbang dan merata.
2. Dalam rangka mendukung dan memperlancar pelaksanaan program pembangunan di desa hendaknya partisipasi masyarakat agar ditingkatkan karena dengan melakukan pembangunan secara partisipatif dapat memperlancar dan mempercepat proses pembangunan ditengahtengah masyarakat.

3. Sosialisasi kegiatan sebaiknya disepaikan ke seluruh warga melalui RT dan RW sehingga seluruh warga dapat berpartisapasi

4. Hasil dari kegiatan ini pemerintah desa dan pemerintah kota ikut sebagai agen promosi yng diadakan melalui pameran dan dianggap sebagai produk unggulan wilayahnya, agar produk yang dihasilkan dari pelatihan bisa menjadi ikon daerah tersebut.

Demikian saran saran sebagai tindak lanjut dari kegiatan pemberdayaan ini, yang bertujuan untuk mewujudkan kesejahteraan bagi masyarakat.

\section{DAFTAR PUSTAKA}

Suhendra, 2006. Peranan Birokrasi dalam Pemberdayaan Masyarakat. Bandung: Alfabeta.

Widjaja, HAW. 2003. Otonomi Desa Merupakan Otonomi Asli Bulat dan Utuh. Jakarta: PT. Raja Grafindo Persada.

Kartasasmita, Ginjar 1995. Pemberdayaan Masyarakat Sebuah Tinjauan Administrasi Pidato Pengakuan Jabatan Guru Besar Dalam Ilmu Administrasi Pada Fakultas Ilmu Administrasi. Malang: Universitas Brawijaya.

Sumaryadi, I Nyoman, 2005. Perencanaan Pembangunan Daerah Otonom dan Pemberdayaan Masyarakat. CV. Citra Utama, Jakarta

http://hitamandbiru.blogspot.com/2012/08/ metode-pemecahan-masalah-problem.html\# ixzz4LIwbYNqp 